\title{
Psychosocial risks and the health of health workers: reflections on Brazilian labor reform
}

\author{
Riscos psicossociais e a saúde dos trabalhadores de saúde: reflexões sobre a Reforma Trabalhista Brasileira
}

Los riesgos psicosociales y la salud de los trabajadores de la salud: reflexiones sobre la reforma laboral brasileña

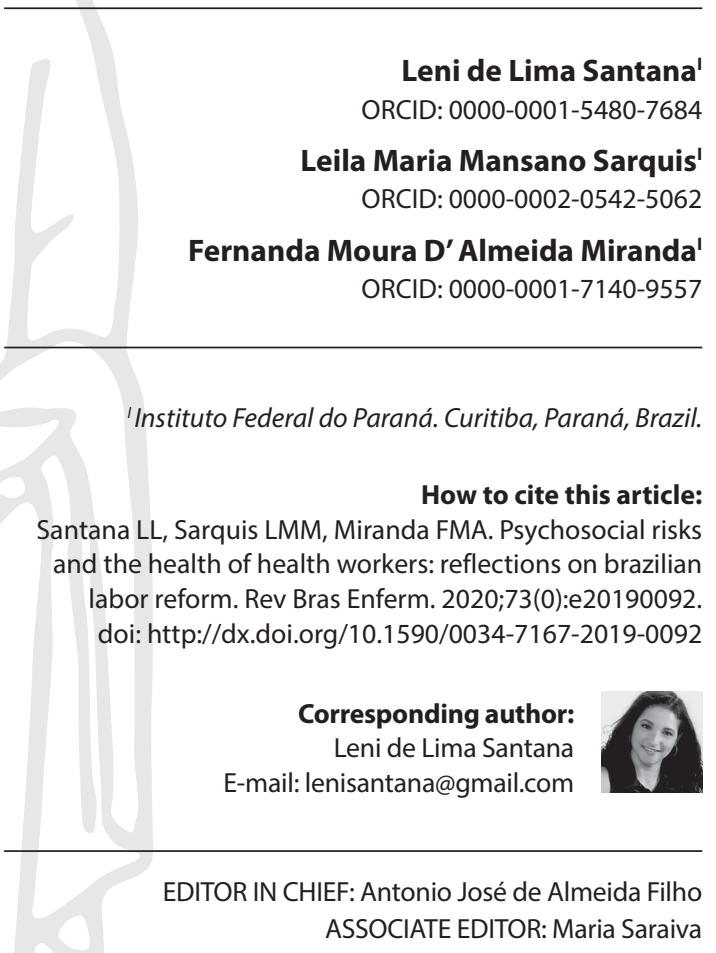

Submission: 02-11-2019
Approval: 04-19-2020

\begin{abstract}
Objective: to reflect on the psychosocial risks and their impacts on the health of health workers in light of the Brazilian economic context and Labor Reform. Method: reflective study on the Brazilian Labor Reform and its impacts on health of health workers. Results: although the changes observed in the labor sphere have contributed to improvements in health and safety policies for, these changes have also contributed to the emergence of new risks arising from work activities, including psychosocial risks, which affect all occupational categories. Final considerations: we understand that the Brazilian Labor Reform carried out in 2017 leads to the weakening of labor relations, increases workers' exposure to risks in the workplace, increases the risk of illness, and opposes the global movement of international organizations aimed at the prevention of aggravation in workers' health and also at preserving their health.
\end{abstract}

Descriptors: Psychosocial Impact; Workplace; Worker's Health; Health Personnel; Occupational Risks.

\section{RESUMO}

Objetivo: refletir sobre os riscos psicossociais e seus impactos na saúde dos trabalhadores de saúde frente ao contexto econômico e à Reforma Trabalhista Brasileira. Método: estudo reflexivo acerca da Reforma Trabalhista Brasileira e seus impactos na saúde dos trabalhadores de saúde. Resultados: embora tenham colaborado para avanços nas políticas de saúde e segurança dos trabalhadores, as mudanças ocorridas no mundo do trabalho - muitas delas decorrentes do modelo econômico globalizado - contribuíram para o surgimento de novos riscos decorrentes das atividades laborais, entre eles os riscos psicossociais, que atingem todas as categorias profissionais. Considerações finais: compreendemos que a Reforma Trabalhista Brasileira conduzida em 2017 induz à fragilização das relações de trabalho, potencializa a exposição dos trabalhadores aos riscos existentes no ambiente laboral, aumenta o risco de adoecimento, contrapondo-se ao movimento global de organizações internacionais voltadas à prevenção de agravos na saúde dos trabalhadores e também à proteção de sua saúde.

Descritores: Impacto Psicossocial; Ambiente de Trabalho; Saúde do Trabalhador; Pessoal de Saúde; Riscos Ocupacionais

\section{RESUMEN}

Objetivo: reflexionar sobre los riesgos psicosociales y sus impactos en la salud de los trabajadores de la salud a la luz del contexto económico y la Reforma Laboral Brasileña. Método: estudio reflexivo sobre los impactos de la Reforma Laboral Brasileña en la salud del trabajador de la salud. Resultados: los cambios en el mundo del trabajo contribuyeron a la aparición de nuevos riesgos derivados de las actividades laborales, destacando los riesgos psicosociales asociados con el trabajo, incluyendo los trabajadores de la salud. Consideraciones finales: se puede ver que la Reforma Laboral Brasileña que tuvo lugar en 2017 induce el debilitamiento de las relaciones laborales, aumenta la exposición de los trabajadores a los riesgos en el lugar de trabajo, aumenta el riesgo de enfermedad en el trabajo, en oposición al movimiento mundial para la prevención de lesiones y la protección de la salud de los trabajadores.

Descriptores: Impacto Psicosocial; Ambiente de Trabajo; Salud del Trabajador; Personal de Salud; Salud Ocupacional. 


\section{INTRODUCTION}

Labor plays a fundamental role in human development. However, work can cause physical and psychological suffering in contexts of precarious and flexible relations, that is, in circumstances where minimum health and safety conditions are not ensured.

Over the past decades, we have observed an increase in the rate of work-related illnesses worldwide, especially those related to psychosocial risks.

According to the International Labour Organization, psychosocial risk results from interactions between workers and their working context. These interactions involve, on the one hand, working environments, organization, and professional satisfaction, and on the other hand, culture, needs, and situations experienced by individuals outside their occupational environment. Workers' perceptions and experiences may interfere positively or negatively with their work performance, job satisfaction, and health ${ }^{(1)}$.

The consequences of exposure to psychosocial risks on workers' health depend, among other factors, on the working environment, the type of economic activity, and the technology involved. Globally, we observe an increase in work-related musculoskeletal disorders (WMSD) and mental and behavioral disorders (MBD), often due to workers' exposure to psychosocial risks ${ }^{(2)}$.

Occupational accidents continue to happen and work-related illnesses remain in a constant increase ${ }^{(2)}$ despite the progress in the field of occupational health brought by improved machinery, technological development, and production of safety equipment. Moreover, new challenges in terms of occupational safety and health emerge ${ }^{(3)}$, but no effective prevention and control measures are being established to address them ${ }^{(2)}$.

Worldwide, it is estimated that 2.2 million people die each year from work-related illnesses and about 160 million workers fall ill because of work-related disorders ${ }^{(4)}$. Thus, disorders related to psychosocial risks become notorious given the physical and psychological illness of workers, which is underestimated in many work environments.

According to data provided by the Brazilian Social Security Institute (INSS), which only includes workers regulated by the Consolidation of Labor Laws (CLT), 549,405 work accidents were registered in 2017 , of which 9,700 are related to occupational diseases. In the same period, there were 2,096 deaths and 12,651 permanent disabilities related to work activity ${ }^{(5)}$. Based on these indexes, we can assume that occupational safety measures, which should eliminate or minimize risks of accidents, are not completely implemented, which leads to a high number of deaths and disabilities.

Although these indexes are significant, it should be considered that different employment relationships are not contemplated by the Brazilian Social Security Institute statistics, such as informal workers and public employees, whose information on accidents is not registered. This indicates that the data on the morbidity of the working population in Brazil do not correspond to reality.

It is important to consider that the non-obligatory notification of work-related accidents and illnesses can be associated with several factors, concerning both workers and employers. Regarding the working class, the omission of records may be related to the subjects' lack of knowledge about their legal rights or the non-attribution of importance to the notification of the accident. Regarding employers and managers, underreporting may occur due to both lack of knowledge and non-compliance with labor law. The Prevention Accident Factor of the Brazilian Social Security Institute may also contribute to the underreporting, which results in an increase in the social security contribution paid by the company depending on the number and severity of the disorder notified.

In addition to issues involving people, there is also the lack of unified national databases that include all workers - regardless of the employment relationship - and the fact that some diseases are not notifiable. These problems hamper the definition, diagnosis and report of diseases ${ }^{(2)}$, thus contributing to the underreporting of several occupational accidents.

The political, economic and working conditions in Brazil increase the exposure of workers to risk factors, especially psychosocial risks, which can influence their health. The Brazilian labor reform (2017) extends the liberty of companies regarding labor contracts, reduces social securities and workers' rights ${ }^{(6)}$, contributes to the increase of competitiveness and to long working hours without appropriate intervals, and also increases the pressure to complete tasks quickly and achieve goals, thus maintaining workers in a constant state of tension fearing unemployment.

Under the current economic state, labor reform exposes workers to an often unfavorable situation and potentially to physical and emotional health risks. Given the unemployment rate in Brazil, the fear of losing jobs induces employees to work overtime or take time in lieu. It also leads workers to agree to reduced rest breaks, extended working hours, reduced vacation time, and other concessions in their rights. Consequently, there may be physical and psychological overload with short, medium, and long term effects.

We emphasize that free time is essential to the physical and mental well-being of workers. High-demand and insecure work environments interfere with physical and emotional recovery after work, which contributes to weak health and low productivity of workers ${ }^{(7)}$. As a result, employers might be dissatisfied with the work produced, and this increases stress and insecurity, and affects the health and well-being of workers, thus creating a vicious circle.

In the health field, besides all aspects involving workers' exposure to occupational risks, there are also factors such as low wages for many occupational categories, long working hours, and lack of resources to effectively perform tasks. In addition to ethical and emotional issues that lead to psychological suffering, compromising the health and quality of life of the subjects.

\section{OBJECTIVE}

To reflect on the psychosocial risks and their impacts on the health of health workers in light of the economic context and the Brazilian Labor Reform.

\section{METHOD}

This reflective paper addresses the influence of the Brazilian Labor Reform on psychosocial risks and the health of health 
workers. The basis for the reflections was defining the problem to be discussed and selecting national and international literature regarding this theme. Ten significant studies were selected to support the construct.

\section{LABOR RELATIONS AND THE HEALTH OF WORKERS}

The approval of Law No. 13,467/2017 - which amends the Consolidation of Labor Laws $(C L T)^{(8)}$ - can be understood as a regression in the field of occupational health in Brazil, despite the legal progresses achieved after the 1988 Federal Constitution, the CLT and the promulgation of the Regulatory Standards by the Ministry of Labor and Employment, which regulate health and safety conditions in several productive sectors and ensure better working conditions. Since the law was enacted, it is possible to increase the flexibility of working hours and workplaces, as well as to telework (home office), which allows workers to perform tasks from their own houses.

Since it is unfeasible to ensure that home settings are appropriate, the exposure of workers to risk factors may increase, especially to ergonomic and psychosocial aspects. These aspects can cause musculoskeletal injuries and work-related mental disorders, thus interfering with the professional's ability to work, and their health and quality of life.

Another worrying aspect that mainly affects health workers is the possibility of women who are pregnant or breastfeeding to work in unhealthy environments of minimum and medium degrees. These women perform their activities in contact with patients suffering from infectious diseases and with infectious materials in hospitals; thus, they inadvertently expose themselves and their children to health risks. We understand that such changes in labor law raise questions concerning the guarantees for workers of safe working conditions that prevent them from falling ill or dying.

Despite their standardizing roles, laws cannot prevent work-related illnesses. It is, therefore, necessary to maintain monitoring mechanisms for such laws in order to provide health and safety for workers. Legislation becomes inoperative without proper supervision, which does not take place if workers do not know their rights - the mere existence of these laws is not synonymous with work safety.

The importance of legislation that ensures decent working conditions, free of risks to workers' health, is unquestionable. However, the current changes in labor legislation have left workers in unfavorable situations due to the dismantling of institutions of support - i.e. the Ministry of Labor and Employment - and the barriers imposed to access labor justice. Another negative outcome of the changes in the Brazilian labor laws is the outsourcing of services and goods, which allows private health insurance companies - and not the Brazilian Unified Health System (SUS) ${ }^{1}$ - to provide healthcare to workers, enabling ethical and moral inconsistencies.

Despite these flaws, the regulatory standards of the Consolidation of Labor Laws remain valid, only lacking active investment for their effective compliance; workers, employers, and managers must be instructed on occupational hazards and on the domino

1 SUS is a publicly funded healthcare system of Brazil, which assists any citizen free of charge. effect as a result of non-compliance - from its effect on workers, families, institutions, and finally, society.

When a worker gets ill, regardless of the origin of the disease, there are consequences for all who surround them: the family, who assists in the treatment of the worker; the employer, who is responsible for the sick leave, health insurance charges, and momentarily replacing the worker; the health system, which bears the treatment costs; and the social security system and taxpayers, who maintain these systems.

In addition, other losses that significantly impact work activity are difficult to account for, such as discontinuity, quality of the service provided, work overload among team members, and, above all, the impact on the lives of sick workers.

\section{PSYCHOSOCIAL RISKS FACTORS ANDTHE MENTAL HEALTH OF WORKERS}

The new forms of work and employment contracts, labor overload, and high emotional demand are some of the factors related to the illness of workers today. The imbalance between work and personal life, the hastened pace imposed by time to complete goals, the lack of control of workers in the organization of their tasks, and the fear of unemployment must also be taken into account ${ }^{(7)}$.

These conditions demand much from workers, whose job maintenance constantly requires more qualification, dynamism, and adaptability. Despite the challenges and the feeling of helplessness in light of the weaknesses brought by labor laws, workers often find themselves at a standstill; due to the economic crisis and the increase in Brazil's unemployment rate, they are willing to remain employed under unfavorable conditions, even if their health is compromised.

These aspects constitute some of the factors that integrate psychosocial risks - an emerging problem in terms of occupational safety and health worldwide ${ }^{(2-3)}$. Psychosocial risks, generally considered one of the biggest challenges in terms of occupational safety and health, are associated with physical and psychological diseases $^{(3)}$ in workers of all age groups and occupations.

The literature has come to a consensus about the nature and identification of work-related psychosocial risks. These risks are attributed to factors such as work requirements, the nature and organization of the work, social relationships, management quality, the interface between work and individual, values in the workplace, justice and respect - within the co-workers and managers hierarchical framework -, health and well-being of workers, and aggressive behaviors. In addition to these factors, we also highlight new ways of working and socializing, migratory flows, and the global financial crisis $^{(7)}$. When these latter aspects are at play, the need to strengthen the economy is implied, and this generally results in unfavorable conditions to the health of workers.

Regarding the main outcomes of psychosocial risks in the work environment, we cite absenteeism, high presenteeism cost, turnover, work overload, decrease in quality of life, motivation and productivity, increases in healthcare expenses and impairment of workers' health, especially considering the increase in $\mathrm{MBD}^{(3)}$.

For health workers, psychosocial risks manifest themselves in different categories and are associated with the specific nature of each profession, the need for continuous education, the 
uninterrupted provision of services, shift changes and working on weekends, working overtime, and shortage of resources ${ }^{(9)}$.

Health workers, in general, are subjected to work environments surrounded by emotions; they are in direct or indirect contact with people in a situation of suffering and patient deaths, which may lead to their own emotional strain. Also, according to the media, they are threatened or verbally and physically abused, and are blamed for the lack of resources and inefficiency of the health system on many occasions.

Another factor that contributes to psychosocial risks is low wages, which makes it necessary for some to have more than one employment bond to supplement their income, and in turn, doubles their workload. Thus, factors such as leisure, social life, professional qualification, and personal care become compromised, which increases the risks of physical and mental illnesses.

In addition to all these factors, poor management practices and inexperienced managers may exert harmful effects on the individual and collective well-being of workers due to abusive practices, such as a 40-hour workweek, mismanaged shift changes, unpaid overtime, limited autonomy, and unreasonable workload. On the other hand, good management practices combined with effective activity time management, stable schedules and contracts, cordiality, and non-aggressive behaviors are favorable to positive psychosocial environments ${ }^{(7)}$.

Current contractual models enhance the existence of psychosocial risks because they endorse insecurity, competitiveness, and as a result, generate work overload; it goes against what many professionals, such as nurses, fight for, which is a reduced workload and proper wages.

Nursing is the only health profession with a 40-hour workweek; in comparison, doctors work 20 hours/week on average. Nurses work caring for patients directly and they are responsible for them throughout their whole 24-hour stay. Less working hours and better wages would ensure more quality care for patients.

For over a decade, legislation that supports the decrease in workload and promotes a national minimum wage for nursing professionals has been under discussion in the National Congress of Brazil. However, since nurses make up the largest workforce in health, employers and managers are not interested in approving these laws. According to their arguments, changes in the current legislature would result in an increase in healthcare costs, both in the public and private sectors. Once again, economic interests are prioritized instead of the health of workers.

Since current labor laws allow direct negotiation between workers and employers, the lack of negotiating capacity for better working conditions and wages and the lack of class movements, such as unions, can result in precarious work conditions and labor exploitation.

The new forms of organization and employment contract provided by the Labor Reform encourage more worker autonomy and greater power of decision on working hours and wages ${ }^{(6)}$. However, in this scenario, the workload also increases, and the imbalance between work and personal life creates tension that exposes workers to psychosocial risks, which may compromise their physical and mental health.

Emotional demands, as a result of exposure to psychosocial risks, subject workers to problems such as stress, depression, anxiety, sleep disorders, and Burnout ${ }^{(7)}$ - major mental illnesses that affect Brazilian workers ${ }^{(5)}$.

In their jobs, health workers are required to pay constant attention to patients, act quickly and efficiently, and display assertive decision-making; failure to meet the proper standards in such situations may incur risks to the safety of patients. Therefore, fatigue, lack of focus, and high levels of stress of health workers can lead to irreversible mistakes for people under their care.

In general, the mental health and psychosocial well-being of workers decline as the level of physiological and cognitive stress increases, which results in neuroendocrine, immune, and emotional reactions such as anxiety, depression, alienation, and apathy. Cognitive reactions can also be affected, such as a lack of ability to concentrate, alteration in creativity, struggles in the decision-making process, as well as harmful lifestyle changes, such as substance abuse and violent behaviors. These symptoms, usually a result of stress, are associated with clinical problems such as musculoskeletal pain, headache, gastrointestinal disorders, heart disease, hormonal disorders, mental disorders, and suicide ${ }^{(7)}$.

Regardless of the factor attributed to the mental disorders at play, ultimately, illnesses harm the work environment, either because of absences for treatment or due to the reduction in productivity and quality of the service provided. Generally, those affected with these conditions tend to have difficulty concentrating - which may lead to mistakes - and adapting to changes - which may lead to conflicts with co-workers or supervisors ${ }^{(10)}$.

In addition, mental disorders can compromise attention, and interfere with communication and productivity ${ }^{(10)}$. In the health field, in addition to financial and productivity issues, it is necessary to reflect on the impacts of these changes on patient safety. Thus, regardless of a causal link, institutions should seek strategies to prevent and manage psychosocial risks at work and the risk of mental disorders in their workers, in order to preserve their health and ensure completeness and safety of patients.

Similarly, government bodies, legislators, and organizations focused on workplace health and safety must develop strategies that minimize the effects of psychosocial risks on the work environment. Actions in this direction extrapolate interventions of individual range and require collective movements, and structural, administrative, and behavioral changes. However, positive responses can be obtained if actions to prevent and promote workplace health are shared between supervisors and workers.

\section{FINAL CONSIDERATIONS}

Due to their impacts on the health and well-being of workers, psychosocial risks are the focus of the scientific community and of many organizations focused on workplace health and safety. Going against this movement, Brazil's 2017 Labor Reform increases the exposure of workers to risks in their workplace and is generally seen as a setback for workers' health because it increases the risk of illness due to work.

Recent changes in labor legislation may contribute to the physical and emotional strain of workers due to increased work overload, fast-paced environment pressure, competitiveness between peers, and inability to enforce their rights, which can 
culminate in abuse of power and exploitation of workers. In this regard, measures to protect workers from the risks to which they are exposed in the workplace must be taken.

A joint effort on the part of class entities, workers, and society is needed to broaden discussions about the harmful effects of psychosocial risks, as well as the need to develop protective measures for the health of workers. Brazil must legally recognize psychosocial risks as occupational hazards and institute programs to manage them in all occupational environments in order to reduce the negative impacts on the health and well-being of workers.

\section{REFERENCES}

1. Organização Internacional do Trabalho (OIT). Factores psicosociales en el trabajo: Naturaleza, incidencia y prevención[Internet]. OIT, Ginebra, Suiza, 1984. [cited 2020 Mar 27]. Available from: http://www.dt.gob.cl/portal/1629/w3-article-60423.html.

2. International Labour Organization (ILO). La Prevención de Las Enfermidades Profesionales. ILO, Genebra, Suiza. [Internet]. 2013 [cited 2019 Jan 23]. Available from: https://www.ilo.org/safework/info/publications/WCMS_209555/lang--es/index.htm.

3. European Agency for Safety and Health at Work (EU-OSHA). Cálculo do custo do estresse e dos riscos psicossociais relacionados com o trabalho. Observatório Europeu dos Riscos: Revisão bibliográfica [Internet]. European Risk Observatory Report. Luxembourg, Spain: Publications Office. 2014 [cited 2019 Jan 23]. Available from: https://osha.europa.eu/pt/tools-and-publications/publications/literature_reviews/ calculating-the-cost-of-work-related-stress-and-psychosocial-risks/view.

4. International Labour Organization (ILO). XIX World Congress on Safety and Health at Work. ILO introductory report: global trends and challenges on occupational safety and health, Report, XIX World Congress on Safety and Health at Work, Istanbul[Internet]. ILO, Genebra, Suiza. 2011 [cited 2019 Jan 23]. Available from: http://www.ilo.org/wcmsp5/groups/public/@ed_protect/@protrav/@safework/documents/publication/wcms_162662.pdf .

5. Ministério da Previdência Social (BR). Anuário Estatístico da Previdência Social 2017[Internet]. 2017 [cited 2019 Jan 23]. Available from: http://www.previdencia.gov.br/estatisticas/

6. Krein JD, Abílio L, Freitas P, Borsari P, Cruz R. Flexibilização das relações de trabalho: insegurança para os trabalhadores. In: Krein JD, Gimenez DM, Santos, AL. Dimensões críticas da reforma trabalhista no Brasil. Campinas, SP: Curt Nimuendajú, 2018. 306 p.

7. Fernandes C, Pereira A. Exposição a fatores de risco psicossocial em contexto de trabalho: revisão sistemática. Rev Saúde Pública. 2016;50:24. doi: 10.1590/S1518-8787.2016050006129

8. Presidência da República (BR). Subchefia para assuntos jurídicos. Lei N. 13467 de 13 de julho de 2017. Altera a Consolidação das Leis do Trabalho (CLT), aprovada pelo Decreto-Lei no 5.452, de 1 o de maio de 1943, e as Leis nos 6.019, de 3 de janeiro de 1974, 8.036, de 11 de maio de 1990, e 8.212, de 24 de julho de 1991, a fim de adequar a legislação às novas relações de trabalho [Internet]. Brasília, DF; 2017. [cited 2019 Jan 30]. Available from: http://www.planalto.gov.br/ccivil_03/_Ato2015-2018/2017/Lei/L13467.htm

9. Messenger JC, Vidal P. The organization of working time and its effects in the health services sector: A comparative analysis of Brazil, South Africa and the Republic of Korea. In: International Labour Office. Geneva. [Internet]. 2015 [cited 2019 Jan 23]. Available from: http://www.ilo. org/public/libdoc/ilo/2015/486945.pdf.

10. Jansson I, Gunnarsson AB. Employers' views of the impact of mental health problems on the ability to work. Work[Internet]. 2018 [cited 2019 Jan 23];59:585-98. Available from: https://content.iospress.com/articles/work/wor2700 